\title{
Uruguay 2018: A Year of Mixed Signals and Open Questions
}

\author{
Uruguay en el 2018: un año de señales mixtas y preguntas abiertas
}

\section{ERICA E. TOWNSEND-BELL}

Oklahoma State University, USA

\begin{abstract}
Uruguay faced significant headwinds in 2018. The Frente Amplio is confronting a slowing economy, and its most challenging election yet. Overall, economic growth is positive, but reduced from the previous year; inflation, unemployment, and the deficit are above target rates. After the loss of a deputy in 2016, the Frente returned to a strong legislative efficiency rate in 2018. However, the party remains vexed by President Tabaré Vázquez's ever lower approval rating, which dipped to a nadir of $30 \%$ by year's end. The party's challenges are extensive. Economic stagnation, low presidential approval ratings, a slim parliamentary majority, and disaffected voters fuse to create substantial unpredictability for the 2019 elections and the country's future political configuration.
\end{abstract}

Key words: Uruguay, Frente Amplio, Latin America, Economic Slowdown, Pink Tide

\section{RESUMEN}

En 2018 Uruguay enfrentó a una cantidad significativa de vientos en contra. El Frente Amplio se encara a una desaceleración de la economía y su elección más desafiante hasta el momento. La tasa de crecimiento fue positiva, aunque reducida respecto al año anterior; la inflación, el desempleo y el déficit están por encima de las metas. Después de la pérdida de un diputado en 2016, el Frente volvió a una fuerte tasa de eficacia legislativa en 2018. Sin embargo, el indice de aprobación del Presidente Tabaré Vázquez bajó a 30\% a fines de ese año, desconcertando al partido. Los retos del Frente son extensos. El estancamiento económico, los bajos índices de aprobación presidencial, la escasa mayoría parlamentaria y los votantes descontentos se fusionan para crear una incertidumbre considerable para las elecciones de 2019, y la configuración política del país.

Palabras clave: Uruguay, Frente Amplio, América Latina, desaceleración económica, marea rosa 


\section{INTRODUCTION}

2018 was a rocky year for the Frente Amplio (FA) and the Vázquez administration, as the country shifts its attention to the 2019 elections. The year ushered in heightened questions about the Frente's electoral possibilities, and what the future holds for the coalition. These concerns sit alongside continued evidence of an economic slowdown, and inquiries regarding the government's ability to reverse course given growing inflation, unemployment, and public debt.

The overarching characterization of 2018 is uncertainty, combined with a tinge of cautious optimism. The economy is in downshift mode. Uruguay's susceptibility to broader regional and international economic patterns outside of its control may mitigate its likelihood of riding out the deceleration trend. The most recent rounds of salary negotiation are almost complete, but much less consensual than in years past, with potentially important, and negative, repercussions for the governing FA's electoral success. However, the party's continued work to enhance social and political inclusion may work in its electoral favor. In either case, the first round of elections will be contested by a large variety of parties and candidates from all party sectors, perhaps shaping a redistribution of the electoral landscape. A part of voters' decision-making may hinge on legislative and executive efficiency, which returned to normal levels in 2018, after a dip due to the temporary loss of the Frente majority earlier in the 2015-2020 governing cycle.

First, the story of the economy was stagnancy. The economic record was mixed in 2018, with several notable downward trends. Overall growth is estimated to have dipped slightly to $2.1 \%$ during the year, down from 2.7\% in 2017 (IMF 2019). Inflation, the deficit, and unemployment continued to be higher than target goals. The exports story was more positive, but managed only a small uptick in growth. The overall picture was of torpid stability. The short-term economic picture looked to continue the deceleration trends noted since 2016, but appears stable over the long term. The finalization of a new paper pulp mill in 2020 is expected to have a meaningful positive impact on Uruguayan investment ratings. The completion of the 7 th round of consejos salariales, while somewhat fraught, is forecast to help with the inflation outlook, and the successful closure of an almost two-year effort to sign a free trade agreement with Chile is also expected to have a positive economic impact (Law 19.646).

Second, the year did include successful passage of some important pieces of social legislation, continuing the Frente Amplio's prioritization of equal rights and inclusivity. The Trans Law (Law 19.684) was the most remarkable among these bills, but the Frente also pushed forward a trafficking bill (Law 19.643), legislation for private sector disability quota (Law 19.691), and a Day of Secularism (Law 19.626), in addition to a law banning the creation or purchase of non-biodegradable or compostable plastic bags (Law 19.655). 
Third, the FA regained its majority in the spring of 2017, but the period of minority government was one of the first factors to indicate, as Bogliaccini and Queirolo (2017) first suggested, that the honeymoon is definitively over. There are now serious questions about the party's likelihood of retaining the majority in either branch of government in the 2019 elections. The party coalition led in most of the early polls and continues to do so. Nonetheless, the rankings continue to exhibit a softer level of support for the Frente than at the same points in previous electoral cycles. Other elements of this pre-election cycle raise questions about the party's electoral future, and whether new political developments - such as the increase in the number of parties campaigning, or the emergence of new right leaning parties-are short-term phenomena, or the early glimmers of wider political transformations.

Fourth, while the Frente's precise electoral future remains an open question, the current government was able to make productive use of its returned majority. Nevertheless, legislative efficiency ratings continued to be depressed in 2018, as they have for the entire $48^{\text {th }}$ legislative cycle. A review of legislation indicates the potential brittleness of the Frente coalition, as it sought to govern with a bare majority.

Fifth, the tendency toward downward outputs is also reflected at the executive branch level. President Tabaré Vázquez's approval ratings maintained their downward slide through the year, helped along by the impacts of the continuing economic deceleration and sizeable rural protests. Un Solo Uruguay, a rural workers' and producers' movement that coalesced in protests over rising gas and energy costs, among many other claims, and with support from other disaffected citizens, claimed mass media attention in the first trimester of 2018. However, executive efficiency ratings improved in this year.

\section{THE ECONOMIC OUTLOOK}

Economic growth was strong for the first 10 years of the FA's tenure, with first Tabaré Vázquez (2005-2010) and then José Mujica (2010-2015) following an approach of steady macroeconomic management that resulted in decreased unemployment and extraordinary growth (Moraes, Guedes and Luján 2012). However, earlier signs of economic strain accelerated by 2016, the year in which unemployment grew and the deficit hit a 25 -year high of $4 \%$, before beginning a soft rebound in 2017 (Bogliaccini and Queirolo 2017; Carneiro and Traversa 2018). Economic growth in 2018 continued on the late upward trajectory that begin in 2017. As with the previous year, 2018 growth ended favorably, but the economic picture was mixed, and consumer confidence was low. 
Figure 1. Consumer Confidence

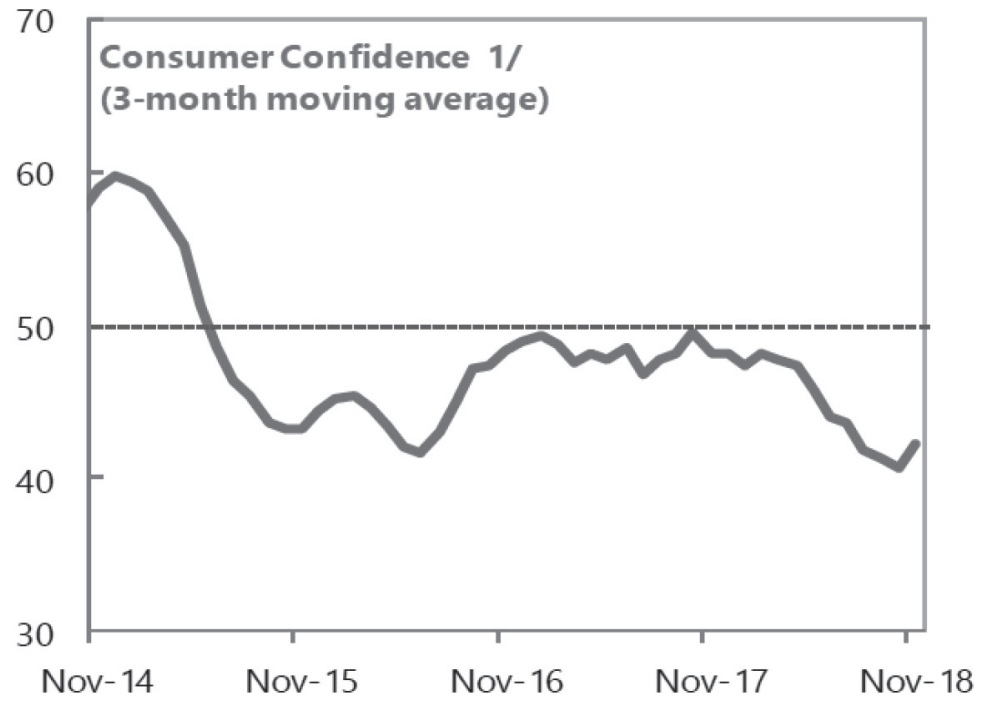

Source: IMF (2019: 27)

In point of fact, the year began on a rocky note for the economy, reflected in the surprise of early protests that took place in Durazno. The protests were originally organized by small farmers, rural workers, and producers frustrated with increasing power costs, taxes, and government bloat, among other things; they were notable for their decentralized nature, and the rapid expansion of adherents. In short order the agricultural center of the protest was joined by protestors from various sectors and locations.

This protest set the tone for the 2018 economic year. Overall growth decreased to $2.1 \%$ for the year, down from $2.7 \%$ in 2017. Inflation continued to hover around $8 \%$, up from an official figure of $6.2 \%$ for the 2017 year, while the deficit lingered at $3.8 \%$ of GDP in November of 2018 . Unemployment stayed at $8 \%$, officially crossing that threshold in the 2018 calendar year (IMF 2019). Fitch Ratings maintained its assessment of the country at a BBB- rating, expressing concerns about the effects of the regional macroeconomic picture, high government debt, inflexibility of the economy, high inflation, and an overall slowing economy, among multiple other factors (Fitch 2018). Similar concerns were outlined by the IMF (2019) and Uruguay XXI (2018).

Still, while there is consensus that the economic outlook is tenuous, economic growth did remain positive, and some areas of the economy, such as trade exports, grew slightly. The actual export growth rate was a scant $0.4 \%$ for the year, but was estimated to have reached $9 \%$ excluding soy crops, which suffered from a severe drought. Other commodities performed quite well, with cellulose, wood, cow's meat, dairy products and vehicles leading the pack (Uruguay XXI 2018). Alongside strong commodity performance was strong and diversified 
commodity demand. China topped the list as Uruguay's largest export trading partner, followed by the European Union, helping it to diversify and shift slightly from the traditional bilateral connections with Argentina and Brazil.

Unsurprisingly, some of those growth sectors are spearheaded by those industries that have increased trade with China, in particular. The data underscore the central importance of commodity exports to Uruguay's economy; thus, the solid diversification of the contemporary commodity outlook is an encouraging development. China and EU-heavy export markets speak to both effective marketing and bilateral trade outreach, and the successful diversification of the export sector, as well as the inflexibility and macroeconomic dependenceregional and international-that characterizes the Uruguayan economy, and troubles the macroeconomic forecast.

In fact, the deficit grew to $3.5 \%$ in 2018 , up from $3.3 \%$ in 2017 , and held stubbornly (Uruguay XXI). These indicators were reflected in the negative Fitch ratings, which affirmed that "Uruguay has seen one of the largest increases in government debt-to-GDP in the 'BBB' category since 2013 when it reached investment grade" (Ministerio de Economía y Finanzas n.d.). As such, the government, which signaled a deficit target of $2.5 \%$, had to extend the target date yet again, to 2020 (IMF 2019). Although the government has communicated a strong commitment to this goal, there is considerable pessimism about the country's capacity to achieve the target by the specified date, due in part to the structure of the Uruguayan economy and the unlikeliness of significant shifts away from the current model, given upcoming elections.

The FA government sought to make some changes meant to strengthen the economy, including Law 19.695, promulgated in October, which addressed military pension reform. The law increased the retirement age and decreased the pension salary. It is forecast to reduce the government deficit by $\$ 500$ million USD. Meanwhile, the successful, if protracted, passage of a bilateral free trade agreement with Chile is expected to offer new economic opportunities as well. And the big story of the last few years continues to be the exploratory investment framework that Uruguay signed with the Finnish company UPM, in beginning negotiation over a third pulp mill, to be located in Durazno. Estimated economic benefits include a 2\% increase in GDP if deal is finalized in 2020 as forecast.

These economic trends, combined with the need for further macroeconomic stabilization on the one hand, and rural protests of citizen discontent on the other hand, mean that upcoming elections will be a referendum on the Frente's governing capacity, and its ability to maintain its compromise with voters. Lánzaro (2011) suggests that the Frente's posture as an alternative to neoliberalism is one of the central reasons for its great electoral support; the pressing need to reign in state spending, maintain growth, and operate as a friendly environment for foreign direct investment may challenge the Frente's ability to manage both set of demands simultaneously (Pérez and Piñeiro Rodríguez 2015). 


\section{Consejos Salariales}

In keeping with their campaign promises, the FA resumed the tripartite wage councils, or consejos salariales, that had been in place from 1943 to 1990, before their suspension in the 1990s, making Uruguay one of the few countries to still actively use such a negotiating model (Etchemendy 2019). ${ }^{1}$ The councils are meant to combine worker and market protection via the expansion of labor rights and union participation in salary decision-making, a goal easily achieved given the 10-point uptick in employment in the first ten years (Moisá et al. 2018, Etchemendy 2019). At the center, then, is an attempted balance between the provision of real wage increases to workers, managing or reducing unemployment, and keeping inflationary spending in check. This balance was untroublesome in the growth period. Businesses were lukewarm to the wage councils from the beginning, but did not mount major opposition, while government, workers, and the PIT-CNT—the country's central labor unionwere in step with their expectations. However, the last round of negotiations, in the 2015-2016 period, showed some fissures as the FA tried to meet all parties' demands in the wake of economic deceleration.

This trend has continued in the current round. The economy is expected to remain resilient, but the current economic picture is concerning. These apprehensions transferred into the $7^{\text {th }}$ round, which began in 2018 and will conclude in 2019. They are the largest in the country's history. In response to economic concerns, the Vázquez government set target salary increase ranges based on the economic health of the sector: $6.5 \%$ for sectors in difficult economic positions, $7.5 \%$ for sectors of intermediate economic status, and $8.5 \%$ for growth sectors, along with a minimum wage of 15,000 pesos- 1500 pesos less than the PIT-CNT sought. Since inflation ranged between 7 and $8 \%$ for the year, only those employed in growth sectors will benefit from an actual wage increase. These guidelines are in effect for a period of 24-30 months, on average, depending on the sector.

The negotiating group for each industry sector consists of seven members by law, including three members of the government, two employer representatives, and two employee representatives, with an equal number of suplentes, or alternates (Law 10.449). $35 \%$ of the agreements were above the salary range recommended by the government, according to the Labor Ministry (Presidencia 2019, 16 March). Minister Ernesto Murro emphasized that these agreements solidify 14 straight years of wage increases, and put salaries $55.5 \%$ above prices. Nevertheless, the government's position on the consejos was somewhat in contrast to other assessments of the negotiations. As Table 1 indicates, there has been a steady and considerable reduction in the proportion of agreements reached by tripartite consensus, from an all-time high of $92 \%$ in 2013 down to just over 53\% by the end of 2018 (Departamento de Psicología Social y Trabajo 2018:

Argentina is the only other Latin American country to make use of such wage models, along with the coordinated European and Scandinavian economies (Etchemendy 2019). 
n.p.). The number of bipartite agreements between employers and employees is notable; in those cases, the parties will revisit the salary guidelines earlier in the proposed timeline in a nod to the disjuncture between high inflation and actual wage earnings.

Table 1. Outcomes of Consejos Salariales

\begin{tabular}{lccc}
\hline \multicolumn{1}{c}{ Round } & 5 & 6 & $7^{2}$ \\
& $(2012-2013)$ & $(2015-2016)$ & $(2018-2019)$ \\
\hline $\begin{array}{l}\text { Number of Field Agreements } \\
\text { \% Tripartite Consensus }\end{array}$ & 132 & 140 & 161 \\
\% Bipartite Consensus: Business & 92 & 64 & 53.4 \\
$\begin{array}{l}\text { and Workers } \\
\text { \% Bipartite Consensus: Exec. }\end{array}$ & 3 & 21 & 36 \\
$\begin{array}{l}\text { Branch and Business } \\
\text { \% Bipartite Consensus: Exec. }\end{array}$ & 2 & 11 & 1.9 \\
$\begin{array}{l}\text { Branch and Workers } \\
\text { Decrees }\end{array}$ & 4 & 2 & 8.1 \\
\hline
\end{tabular}

Source: Departamento de Psicología y Trabajo Social 2018: n.p.

This fraught picture reflects concerns previously outlined by Bogliaccini and Queirolo (2017), who suggested that the government needs to structure a stronger negotiating model that can operate successfully in the face of economic deceleration.

One concern, in addition to those noted above, is that even the strongest agreements only affect the formal work force. From a high of $43.9 \%$ in 2003 down to $24 \%$ in 2017, Uruguay is among the lowest in the region in terms of informality, but its numbers are still robust (Moisá et al. 2018; World Bank 2019). These figures add fuel to fears that the wage agreements will boost real wages for those employed in growth sectors, but do nothing to address unease about unemployment or informality. Afro-descendants feature as a part of that population outside of the formal workforce, with a 3.2\% greater likelihood of group membership than other citizens (Freire et al. 2018: 79).

Poverty rates have decreased for both the general and afro-descendant populations over the FA's tenure. The general poverty rate measured at $9.4 \%$ in 2016, and dropped appreciably, to $7.9 \%$ in 2017, before moving back up slightly

The $7^{\text {th }}$ round will complete in 2019 , and is projected to include at least 189 convenios in total. All data for the $7^{\text {th }}$ round reflect the most up-to-date information as of 15 December 2018, the day that the government typically recesses for end-of-year vacations. 
in 2018, to 8.1\% (Carneiro and Traversa 2018, INE 2019). ${ }^{3}$ The afro poverty rate remains, stubbornly, almost double that of the general poverty rate. The afro poverty rate has undergone the same downward trajectory of general poverty over the years, deviating considerably from the rate of $48.4 \%$ measured in the first year such data addressed racial variation (INE 2009). Still, it experienced a $0.5 \%$ jump in 2018 , from $16.9 \%$ in 2016 to $17.4 \%$. This is in contrast to the $0.2 \%$ jump from 2017 to 2018 , reflected in the general poverty rate.

The consejos salariales cannot be the only tool conscripted to address these structural trends, but they are certainly one strategy the Frente has championed for the purpose of attacking systemic class (though not race) inequality. As Carneiro and Traversa (2018) affirm, the collective negotiating model has remained effective in meeting its stated objectives thus far, but its future success may require some additional restructuring to continue to meet even these baseline goals, much less the bigger goal of broad class inclusion across diverse groups.

\section{COYUNTURA SOCIAL}

Still, while the consejos may turn out to pose a serious challenge for the FA's electoral future, they feature as one of the signature progressive policies implemented by the party over its 14-year reign. Uruguay has earned an international reputation for its progressive policies, favoring social inclusion. This work has mostly taken the form of new laws that can be divided into three approaches. The first include a long list of progressive, primarily classbased policies, the consejos salariales among them. Many of these were passed and implemented during Vázquez's first administration, and in many cases maintained or consolidated during Mujica's term; the list includes health insurance, tax reform, and more than 40 laws addressing labor rights (Pérez and Piñeiro Rodríguez 2016).

A second set of laws are of a more libertarian nature, authored under the first Vázquez presidency and continued during Mujica's presidency (Pérez and Piñeiro Rodríguez 2016). These feature the abortion law, the legalization of gay marriage, all passed in 2013, and a long list of other laws passed in the service of LGBT rights. ${ }^{4}$ The majority of these laws are organized around an equal rights framework in which individual rights take primacy.

Recently, the FA has introduced limited sets of redistributive laws, such as Law 19.122, which sets a public employment quota for afro-descendants, the one-

Only general and afro poverty rates are available annually.

Other LGBT laws passed include same-sex adoption in 2009, military service in 2009, the updating of accurate gender identity on the civil registry in 2009, in-vitro fertilization benefits in 2013, and automatic parenthood benefits after the birth of a child in 2013. Anti-discrimination laws, passed in 2003 and 2004, preceded the Frente Amplio's governance. 
time gender quota law adopted for the 2014 elections, and the follow-up gender quota established in 2017, in addition to two laws passed in 2018..$^{5}$ One of these was an update to the pre-existing (and poorly enforced) disability quota, requiring that it be applied to private businesses as well as public entities. The other, the Trans law, garnered major attention. Its successful passage means that the public health service now covers gender confirmation surgery and hormone treatments, in addition to government provision of scholarships, reparations for those who suffered under the dictatorship, a 1\% public sector employment quota, and the ability to freely change one's name and self-identity by choice. Thus, the regulation continues the expansion of redistributive laws that vary in the degree to which they are widely known, as well as in the percentage of the redistributive effect. These range from a low of $1 \%$ for the Trans Law, to an $8 \%$ mandate on public employment posts for those who identify as afro-descendant, and $33 \%$ (up to $67 \%$ ) requirement for those candidates who identify as female. Collectively, they create new approaches to, and arguments for, social inclusion by the state.

Thus, Uruguay maintained its reputation for progressive social inclusion, an openness that extends to native and immigrant populations. 2017 marked the first year in which Venezuelans topped the immigrant list, displacing Argentines from their consistent first place spot (Peralta 2018: 4-10). At 14,348, 2018 marked a record in the number of residencies granted to immigrants. The majority of these proceedings were transacted through the Chancellery (Ministry of Foreign Relations), and of those, half were Venezuelan; the remainder of the proceedings were processed through the National Migration Bureau, where half of those transactions were initiated for Cuban immigrants (El Observador 2018, 18 December).

\section{ELECTIONS AND POLITICAL OUTLOOK}

The Uruguayan party system has evolved over time to its current equilibrium, in which the Frente Amplio holds a majority and the National Party constitutes the main opposition bloc (Buquet and Piñeiro 2014). The Colorado Party (PC) and National Party (PN) constituted the major two players in the party system prior to 1971 and maintained their dominance even as the FA entered the scene as a significant third party in the period from 1971-2004. The Uruguayan electorate is highly polarized, but the shift toward the current equilibrium model reflects the shift of the parties, rather than a realignment of voters (Moraes 2015). As the traditional parties gradually gravitated toward the extremes, overtime, the FA moderated its message from a more radical left position to claim the vacant center space (Luna 2007; Lánzaro 2011).

5 The 2017 gender quota law establishes that 1 of every 3 be a female (and that at least 1 identify as male). It is effective for parliamentary, departmental, municipal, and internal party elections. 
The current economic repercussions will play a serious role in the upcoming elections, and the stakes hinge, in part, on the FA's ability to maintain its hold on the center. The 2019 elections will function as a referendum on the Frente Amplio's performance thus far, its plans for the future, and the opposition parties' ability to govern. ${ }^{6}$ Moreover, the election is something of a test of increasing concerns that the party coalition is beginning to fragment over the distinct directions its partners wish to take. The effects of slow growth and regional challenges make opportunities for more high impact policy change challenging, and constrain the redistributive model. Meanwhile, these same changes compromise the Frente's organizing model, in which clear and consensual programmatic priorities, rather than ideological agreement or conversion, govern decision-making and governance (Canzini 2018).

A part of the discontent is organized around the comparative inactivity of the Vázquez administration, and the Frente's failure, after three governing cycles, to make noteworthy strides against entrenched structural issues such as educational inequities and agrarian reform (Caetano 2017; Canzini 2018). These concerns, combined with questions regarding the leftist party's ability to govern during periods of economic deceleration, invite challenges on both the left and the right (Caetano 2017).

In the typical coalition model, parties that are farther away from the ideological center of the ruling party are not likely to enter the government, or to have a say in the party's program (Alemán and Tsebelis 2011). But the Frente Amplio model balances smaller factions' priorities with the preferences and policy positions of the larger factions that actually obtain parliamentary seats; thus, the typical coalition logic is somewhat subverted (Yaffé 2013). The model traditionally worked via an institutional structure that is based on compromise and inclusiveness. The FA remains the only mass party in the region with a structure that includes dedicated opportunities for rank-and-file party militants to indicate their preferences on policies and programming (Pérez Bentancur et al. 2019). Yet, several developments, including the protracted debate over the Chilean Free Trade Agreement, reform of the Caja Militar, and the failure of the party finance law, imply that the balance may be shifting away from the compromise model.

A significant point of concern for the upcoming election is how many disaffected Frente Amplistas there are, and how many are unhappy enough to defect, or vote a blank ballot. The Frente Amplio and Partido Nacional began the campaign cycle fairly even in the polls, with the Frente polling close to 15 points behind where it was in the fall of 2013 (Bottinelli 2018, 10 September). Still, while poll numbers were low compared to the same period in other electoral cycles, the FA still held the early lead across the varied vote polls, rising slightly each month (Bottinelli

The elections take place in three rounds, beginning with internal party elections on 30 June 2019, followed by the general election on 27 October. Should a run-off be necessary, it will occur on 24 November 2019. 
2018, 10 September; Cifra 2019, 6 March). Hence, it may continue to benefit from the trend of low electoral volatility common to ideologically distinctive parties (Su 2014). The Frente ranks as the most ideologically congruent party in Uruguay, and among the highest in the region (Buquet and Selios 2014). Such a foundation may or may not be sufficient for the primary candidates who are running this cycle. These are Carolina Cosse, the MPP majority's candidate and previous Minister of Industry, Energy and Mining; Mario Bergara (Lista 611 Brazo Libertador), Óscar Andrade of the Partido Comunista and Lista 711, and the front runner Daniel Martínez, mayor of Montevideo until he stepped down to campaign for office. Daniel Martínez is a Socialist Party stalwart backed by Vázquez and the more center leaning factions of the coalition, while Carolina Cosse is promoted by former president José Mujica and some of the more center-left elements of the alliance.

Of course, another important factor will be the performance of the other parties, and perhaps the effects that potentially low turnout for the internal elections will have on candidate selection for the general election. The 2014 internal elections continued a trend of downward participation in voting for these contests. Even as the internal elections loom, the number of Uruguayans aware of their date is a scant 2\% (Bottinelli 2019, 8 March).

The PN's internal election will be characterized, first, by the large number of candidates contesting the election. Competitors include Todos candidate Luís Lacalle Pou, the current front runner, followed by Jorge Larrañaga, Juan Sartori, Enrique Antía, Verónica Alonso, and Carlos Iafigliola, all of whom have dialed in on a message that the people have tired of, and can no longer afford to be governed by, the Frente Amplio, and should choose the Partido Nacional instead. ${ }^{7}$

Larrañaga and his Juntos faction have doubled down on this message, both with his Vivir Sin Miedo campaign, and early campaign rhetoric heavily centered on the argument that the Uruguayan society cannot sustain another 5 years of the Frente. 58\% of likely voters signal they will vote in favor of the Larrañagabacked plebiscite, the Vivir Sin Miedo Campaign. 
Figure 2. Support for the Vivir Sin Miedo Amendment

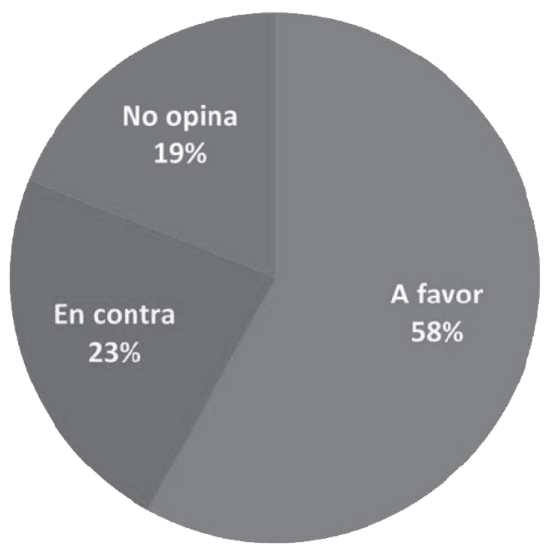

Source: Cifra (2019, 18 March)

Larrañaga's petition included more than 400,000 signatures, which the Electoral Court is currently reviewing. The proposed constitutional amendment would allow for night raids (with judicial authorization), the creation of a National Guard, and mandatory sentencing requirements (El Observador 2018, 18 October). The plebiscite components carry with them several key divisions that could have varied electoral repercussions. There is a rural-urban divide in support, as well as a class divide and a party divide, with greater support from rural, lower class, and PN voters (Cifra 2019, 18 March). While the uptake of the plebiscite is an open question, the party is definitely in step with citizen concerns on security. More than $40 \%$ of citizens rate crime as a primary concern, compared to just $12 \%$ of legislators. In a reverse pattern, $22 \%$ of legislators highlight inequality as a problem, in contrast to only 3\% of citizens (Buquet and Selios 2014: 198).

As of late 2018, the overall percentage in favor of a referendum was precisely the same as it was five years ago in the run up to the 2014 election, but there has been a shift in those who fall outside this category; the proportion of those in the "opposed" category has declined by 10 percentage points, and the proportion in the "no opinion" category has correspondingly increased by 10 percentage points between 2014 and 2018. Neither the other National Party candidates, nor other opposition candidates signaled early support for the amendment. The campaign has therefore helped put a prostrated Larrañaga back in the mix of notable candidates, but it has not been enough to propel him to the front of the group. It is also unclear whether a positive vote for the amendment would translate to a vote for Larrañaga.

Bogliaccini and Queirolo (2017: 598-99) affirm that the "atomization" of the PC has been a fact for some time, though the size of the loss has varied each electoral 
cycle since 2004. After 168 years as a dominant Uruguayan political party, the PC achieved a mere $10.4 \%$ of the vote in the 2004 elections. Its prospects improved somewhat in the 2009 election, in which it received $17 \%$ of the vote, before dipping back to $13 \%$ in the 2014 cycle. It is an open question whether some of the alterations that began in 2017 can influence this pattern. The most central of these was previous Colorado front-runner Pedro Bordaberry's (Vamos Uruguay) decision not to run as a presidential candidate, and to step down from the Senate at the end of his term. This was a significant departure for Bordaberry and a considerable change for the Vamos Uruguay faction, left temporarily without a leader. As Bogliaccini and Queirolo (2017) suggested, these shifts, along with the defection of two members to the newly formed Partido de la Gente, have fomented some internal party realignments in the lead-up to the next election. Several names were thrown around to fill the leadership post, and eventually most of the Vamos faction merged into the Ciudadanos sector, headed by candidate Ernesto Talvi. The PC has two other main candidates: José Amorín Battle (Uruguay Batllista), and former president Julio María Sanguinetti (Batllistas), the 2018 front-runner.

In fact, multiparty, coalition-based democracies are quite common in Latin American, and Uruguay is no exception (Chasquetti 2007). Realignment and coalition politics have been common parts of the Uruguayan electoral story. Totally new parties, formed with names completely new to politics, less so. Yet, a new development for this year's elections is the entry of several new parties, a number of right-leaning parties among them. Like Larrañaga, the recently formed (2016) Partido de la Gente's Edgardo Novick, a former Colorado, is running on a platform that also emphasizes security issues. These developments reflect both a rising number of parties prioritizing such concerns, and simply a rising number of parties. With the exception of the 1994 electoral cycle, in which 15 qualified parties competed, it has been the norm for a single digit number of political parties to contest elections. The figures rose slightly, to 10, in the 2014 electoral cycle, and more sharply, to 15 qualified parties certified by the Electoral Court, in this 2019 cycle (Corte Electoral n.d.).

Hence, 2019 is noteworthy for the rise of several right and, in some cases, far right, and ex-military aligned, leaning political parties. These include the aforementioned Partido de la Gente (PG), the Republican Order Party, with presidential candidate Hugo Grossi, a retired Infantry Colonel, and Cabildo Abierto, which has forwarded recently dismissed Army Chief Guido Manini Rios as its presidential candidate. However, in keeping with Uruguayan political traditions, none of these parties actually identify themselves as right-leaning, instead leaving that end of the political spectrum formally vacant (Álvarez 2018). They thus open up the option for coalition or outright merger, pending the 2019 election results.

These right-leaning (in policy if not in designation) parties are not likely to be big contenders in the elections in their own right, especially because not all of them are actually new to politics. As Álvarez (2018) affirms, the image of newness 
is belied by the fact that some parties, such as PG, are spearheaded by preexisting politicians who have simply shifted their organization and allegiance. However, they do pose two key questions. First, how might they disrupt the electoral chances of the front-runner parties? And what does their entry onto the scene mean for the trajectory of Uruguayan politics? Thus far, Uruguay is the sole remaining member of the vaunted "Pink Tide" and may continue to be after October 2019, but, even so, the rise of not one but several right leaning parties might be taken to mean that the right is encroaching, however slow and unpredictable that emergence may be. On balance, recent economic and political shifts indicate signs of a challenge to the Pink Tide, if not cessation.

\section{Poder Legislativo}

The Uruguayan parliament's two chambers are comprised of a 99-seat House of Representatives and a 31-member Senate, including the Vice President of the Republic. Table 2 highlights the FA's bare majority in the current legislature.

Table 2. Distribution of Seats by Chamber and Party 2018

\begin{tabular}{lcccccc}
\hline & $\begin{array}{c}\text { Frente } \\
\text { Amplio }\end{array}$ & $\begin{array}{c}\text { Partido } \\
\text { Nacional }\end{array}$ & $\begin{array}{c}\text { Partido } \\
\text { Colorado }\end{array}$ & $\begin{array}{c}\text { Partido } \\
\text { Indepen- } \\
\text { diente }\end{array}$ & $\begin{array}{c}\text { Unidad } \\
\text { Popular }\end{array}$ & $\begin{array}{c}\text { Partido de } \\
\text { la Gente }\end{array}$ \\
\hline $\begin{array}{l}\text { Represen- } \\
\text { tatives } \\
\text { Senate }^{8}\end{array}$ & $50(51 \%)$ & $31(31 \%)$ & $11(11 \%)$ & $4(4 \%)$ & $1(1 \%)$ & $2(2 \%)$ \\
\hline
\end{tabular}

Source: Parlamento del Uruguay (n.d.-a); Parlamento del Uruguay (n.d.-b)

The Executive Branch's efficiency rate was back up in 2018, after a slowdown due to the temporary loss of the majority in 2016 (Carneiro and Traversa 2018). Yet, the lowest efficiency rate was marked in 2015, following a downward trend that began in 2014. Table 3 highlights the legislature's role in relation to this reduced productivity. cated. This leaves the party with no sitting senators and increases the Colorado Party's share of Senate seats to $4(13 \%)$. 
Table 3. Parliamentary Legislative Efficiency Rate

\begin{tabular}{cccc}
\hline Legislature & Year & Annual & Accumulated \\
\hline $46^{\text {th }}$ & 2005 & $10 \%$ & $10 \%$ \\
& 2006 & $11 \%$ & $16 \%$ \\
& 2007 & $9 \%$ & $20 \%$ \\
& 2008 & $11 \%$ & $26 \%$ \\
$47^{\text {th }}$ & 2009 & $9 \%$ & $30 \%$ \\
& 2010 & $8 \%$ & $8 \%$ \\
& 2011 & $9 \%$ & $13 \%$ \\
& 2012 & $7 \%$ & $16 \%$ \\
& 2013 & $7 \%$ & $19 \%$ \\
$48^{\text {th }}$ & 2014 & $6 \%$ & $\mathbf{2 3} \%$ \\
\hline 2015 & $2 \%$ & $2 \%$ \\
& 2016 & $4 \%$ & $5 \%$ \\
& 2017 & $6 \%$ & $10 \%$ \\
& 2018 & $6 \%$ & $\mathbf{1 4} \%$ \\
\hline
\end{tabular}

Source: Programa de Estudios n.d.-a

Nonetheless, 2018 did see the passage of several major pieces of legislation. Among these were Law 19.695, known as the reform of the Caja Militar, which introduced the reform of military pensions. It increased the amount of years served and decreased the monthly benefits for those with 15 years or less of service (those with more than 15 years will stay in the current retirement system). Law 19.684, more commonly known as the Trans Law, was another coup. These bills, along with other important pieces of legislation-such as the free trade agreement with Chile, strengthening of the disability quota, rules outlining the rights, responsibilities and expectations of private security, a trafficking law and more-were made possible by the return of the Frente Amplio majority.

The work that the Frente-led legislature helped to produce is notable. Equally notable is additional evidence of the fragility of the coalition, especially as it works with a bare majority of exactly 50 representatives that allows no room for defection. The Caja Militar reform bill passed the House of Representatives by a vote of 51 out of 95 , but only after a protracted duration that required weighty and public inter-party negotiation. Indeed, one widely read newspaper's reporting of the vote is filed under the heading: "Nacional: Fin de Polémica" (El Observador 2018, 18 October). Similarly, the Free Trade Agreement that was finally passed with Chile took more than two years. Ratification was defeated by the more left-leaning flanks of the Frente Amplio coalition, the Partido Comunista and Casa Grande sectors among them, as recently as the May 2018 Frente Amplio plenary meeting (MercoPress 2018). The agreement finally 
reached internal approval during the 23 June party congress meeting, securing $86(54 \%)$ votes in favor, and 65 against (41\%), with $8(5 \%)$ abstentions (EMIA 2018). These negotiations were prolonged, but ultimately successful. Other attempts ended less positively. FA representative Darío Pérez's (Liga Federal) decision not to support the Law of Political Parties, a major legislative priority of the Frente, led to its failure in the final month of 2018 (El Observador 2018, 20 December). The bill, which passed the Senate with multi-party support, would have eliminated anonymous donations, prohibited commercial support of candidates, put maximum limits on self-donations, and established ratios for free state television advertising. These cases add evidence to the concern that the Frente Amplio's coalition may be fraying. They also suggest that the current model requires some substantial tweaking if the coalition is going to continue to hold together, and do so productively.

One such adaption in the model may already be underway, though its reach is limited thus far. Former President José Mujica (2010-2015) noted his fatigue, and announced his retirement from the Senate and daily political life in August 2018. He advertised the rationale as a desire to allow more time for farming. This preference accords well with a renewal plan for the MPP, the FA's largest faction, and one of the most left leaning, meant to make space for newer militants in the ranks (Gil 2018). Mujica has indicated that he still plans to help with elections, thus creating a model in which long-serving politicians move aside to make room for younger militants with new or varied ideas, supported by those with actual governing experience, institutional memory, and knowledge of strategy. It is possible that such a model could serve as a winning strategy for the MPP specifically, and the Frente more broadly, were it to adopt a similar approach.

\section{Poder Ejecutivo}

Unlike legislative efficiency rates, executive efficiency rates did begin to rise in 2018, as they followed the usual trend of executive dominance in the initiation of legislation (Carneiro and Traversa 2018). By December 2018 (month 46 of the $48^{\text {th }}$ legislature) proficiency was roughly on pace with the same month (46) of the $47^{\text {th }}$ legislature. That is, 66\% efficiency in December 2018 compared to $67 \%$ efficiency in December 2013 (Programa de Estudios n.d.-b). However, this shift back into the black took most of the year, not taking root until October of 2018, and it could not make up for the overall reduction in bills introduced in the $48^{\text {th }}$ legislative cycle thus far. 
Figure 3: Executive Branch Legislative Efficiency Rate

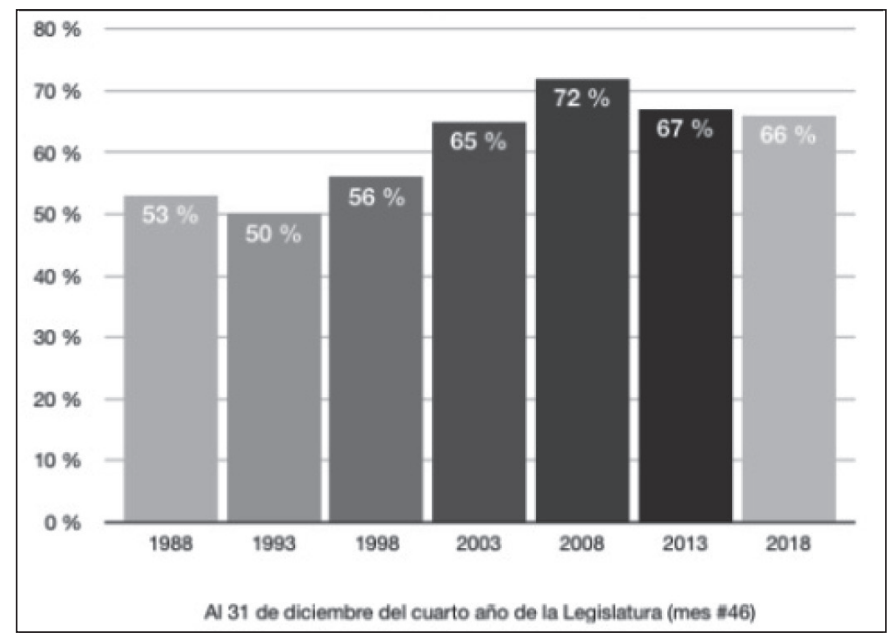

Source: Programa de Estudios Parlamentarios n.d.-b

The government produced 265 fewer bills in 2018 than in 2015. Since the $42^{\text {nd }}$ Legislative period (1985-1989), there have been an average of 226.5 fewer bills introduced in the final year of each period than in the first year. Thus, a 265-bill difference between year 1 of the current legislative period and the penultimate year of the current cycle is quite an increase above the average, and begs the question of how high the difference might climb in 2019-the actual final year of the cycle.

Figure 4. Difference in Number of Bills Introduced in First and Last Year of the Legislative Cycle, 1985-2018

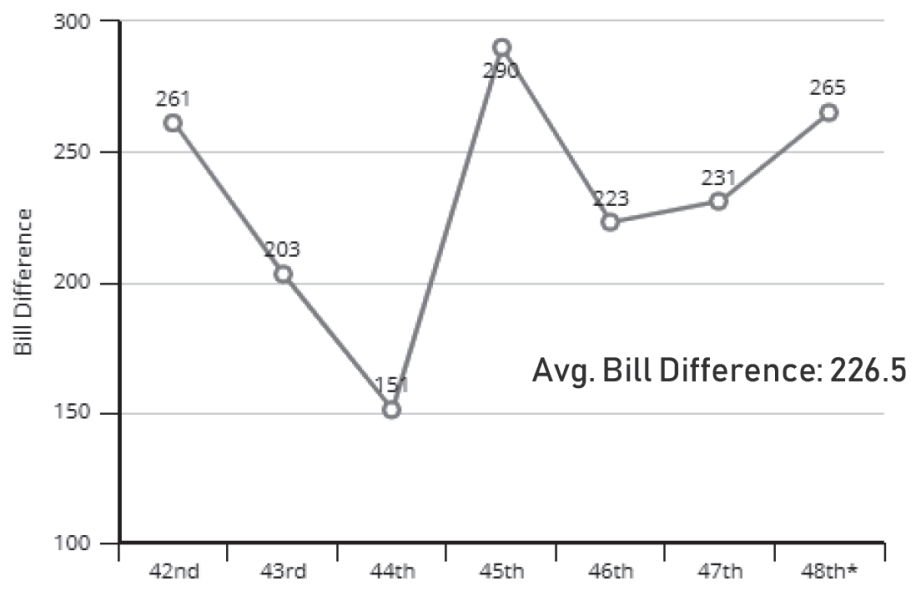

Source: Author Calculation using Producción Parlamentaria Data, Programa de Estudios n.d.-a 
It seems that Tabaré Vázquez laid the groundwork for his penultimate presidential year in December of 2017, when he made the decision to postpone talks with rural unions concerned by the price increases on various goods that would take effect on 1 January 2018. President Vázquez's decision to postpone meetings scheduled with rural producers interested in voicing their displeasure seemed a step too far. Power rate increases were a central aggravation given prior UTE signals that prices could actually decrease, due to the success of the country's varied green power initiatives (Mercopress 2018). Major protests commenced, under the banner of "Un Solo Uruguay." These protests were lauded for their allegedly decentralized nature, the degree to which they surprised the Vázquez administration, and for the breadth of support they captured. In fact, the protests received substantial backing from organized business. Still, this strong support organized around antipathy to significant prices increases on a bevy of goods. These price hikes included the previously noted power cost increases, along with surges in food, gas, water, and bus fares as well. They also reflected frustration with Vázquez himself; grievance with Vázquez and his administration built steadily since the first big drop in approval ratings appeared in 2015, in the very first year of his presidency. The more than 10-point decrease in support measured in the first year moved to a new low of $30 \%$ for the year, after dipping as low as $27 \%$ earlier in the calendar period. Unlike his previous presidential terms, Vázquez's low approval ratings this term appear unlikely to reverse themselves in this cycle. This state of affairs reflects Vázquez's propensity to let his cabinet ministers take the lead on many matters of governance and to work around, rather than through, the party coalition on his specific policy priorities (Pérez and Piñeiro Rodríguez 2016, Bogliaccini and Quierolo 2017).

Figure 5. Tabaré Vázquez's Approval Ratings, 2015-2018

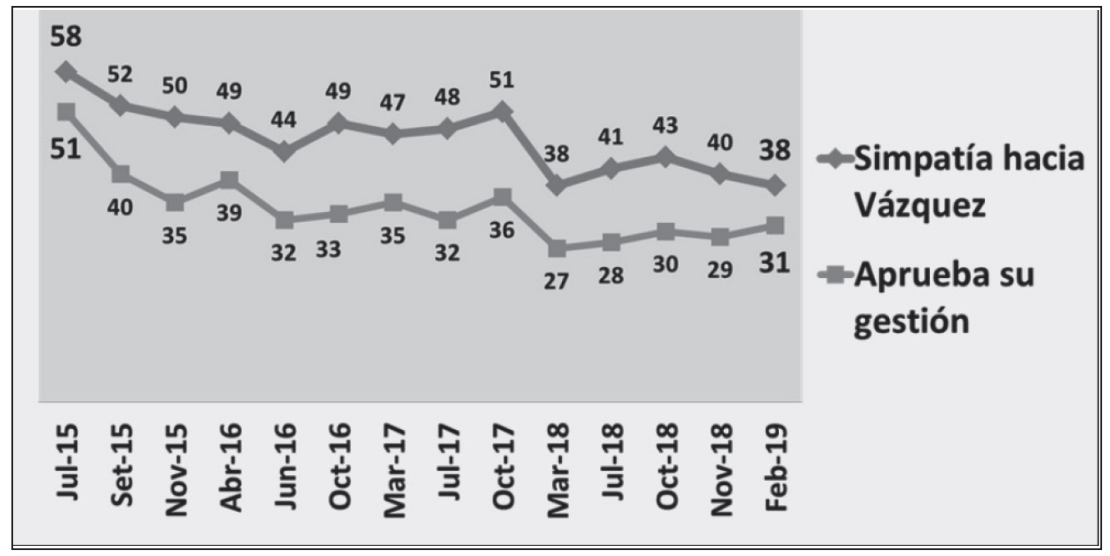

Cifra 2019, 13 March 2019 
The grievance with Vázquez extended to his Agricultural Minister Tabaré Aguerre, who had served in this position since 2010. Like President Vázquez, he was faulted for being out of touch and seemingly unconcerned with the needs of producers and workers. In light of the protests, he submitted his resignation in December of 2018, which became effective in January of the next year. This shift was only the second change in the composition of Vázquez's cabinet since he assumed office in $2015 .^{9}$

Piñeiro and Cardeillac (2017) note that the first Frente government focused on economic recovery, while the second oversaw extraordinary rights expansion. The third Frente government also touched on parts of these policy priorities, alongside the aforementioned passage of some focal legislation, but lacks strong association with any particular set of issues.

Table 4. What was the Principal Success of the Vázquez Government? Spontaneous Responses

\begin{tabular}{lc}
\hline Inclusión Social, Equidad, Políticas Sociales & $11 \%$ \\
Economía, Estabilidad, Baja Inflación & $9 \%$ \\
Salud, Fonasa, Plan de Cuidados & $6 \%$ \\
Consejos de Salarios, Aumento de Salarios, Jubilaciones & $3 \%$ \\
Obras Públicas, Infraestructura & $3 \%$ \\
Mejores Educativas & $2 \%$ \\
Otros Logros & $10 \%$ \\
Ningún Logro & $31 \%$ \\
No Opina & $25 \%$ \\
Total & $100 \%$ \\
\hline
\end{tabular}

Cifra $(2019,13)$.

According to the same Cifra survey, 11\% of respondents credited the Vázquez administration for strides in social inclusion, the largest set of measures for which the administration received credit. By contrast, the majority of respondents were clear in crediting the administration with no success.

Whereas this evidence indicates the lack of a programmatic anchor for the third Frente Amplio administration, citizens are less tentative in outlining a central failure. In a follow-up question $41 \%$ of respondents tasked the Vázquez administration with security failures. Education, while not a close second, followed at 9\% (Cifra 2019, 13 March). As noted, executive efficiency had

9 The other change, through the 2018 period, was the replacement of Defense Minister Eleuterio Fernández Huidobro with Jorge Menéndez. Fernández Huidobro, who served as Minister from 2011 to 2016, died in office. 
risen in 2018. The Executive Branch reached a 99\% legislative efficiency rate (Programa de Estudios n.d.-a). However, it is worth noting that a fair number of the 142 laws promulgated by the Executive Branch in 2018 fell into one of two categories. A conservative review of the legislation highlights 36 laws that fall under administrative housekeeping, such as the naming of schools, roads, holidays and monuments, and the granting of ex gratia pensions. ${ }^{10}$ An additional 21 laws are short-term directives that addressed the kinds of issues that rural protestor's raised and moderated some of the worst of the price increases mentioned earlier. ${ }^{11}$ These two categories combine to account for 47 of the 142 laws passed for the year, or $40 \%$. In short, while the administration was productive, it is not clear that it was work of the sort that Uruguayan citizen's desire, or will continue to vote for.

\section{CONCLUSION}

In brief, 2018 is best described as mixed in outlook across every political dimension. Uncertainty characterizes the economic picture, and the electoral outcome. As a result, the future trajectory of the governing branches and social inclusion are also uncertain. Legislative efficiency remains down for this cycle, and the trend seems likely to remain as such for 2019, given current indicators. Executive efficiency was up, if not celebrated. Still, the government was able to produce important pieces of legislation for the year, including social legislation.

If the Frente Amplio manages to hold the executive, the next five years will clearly bode differently than if the Partido Nacional, the most likely competitor, manages a return to power. At the legislative level it seems quite possible that the Frente Amplio will lose its majority. Such an outcome will mandate a new governing model, even if the Frente were to hold the presidency. It will require a full transfer back to large minority opposition party on both fronts if the party's electoral majority bid is unsuccessful. In any of these scenarios it is apparent that the alliance will need to revisit its coalition model to discern what changes are needed and how to best affect them. One important part of this strategy could be to follow that route opened by José Mujica, and make a concerted effort to attract new militants to the coalition's sectors, broadly. Daniel Martínez, should he be successful, is tasked with shifting this course.

Similarly, open questions accompany the broadening of the opposition, as manifested through a larger number of candidates overall, a large number of parties, and larger coverage of the political spectrum. In regard to Larrañaga's

10 Other laws included in this category include naming of a cemetery, temporary naming of cities, or the elevation of geographic areas to city status, and a bill allowing the Administración de Obras Sanitarias (OSE) to contract new workers. These bill categories, along with those listed above, constitute the full set of the 36 laws.

11 These are Laws 19.592, 19.595-19.596; 19.602, 19.611-19.615; 19.620, 19.637, 19.648-19.649, 19.663-19.665,9.674, $19.686,19.690,19.692-19.693$ 
Vivir Sin Miedo campaign, the previous attempt at a security led campaign was not well received, and the current attempt will be challenged both by the strong Frente Amplio pushback against it, and the entry of Cabildos Abiertos and Partido Orden Republicano. The fact that these two right leaning parties are led by, exmilitary leaders- in one case quite recently so-may raise considerable questions about Vivir Sin Miedo and Larrañaga's chances, in either direction. ${ }^{12}$ It seems probable that any non-Frente candidate that manages to win the Executive would have to preside over a mixed government in which their party would not hold an outright majority. While in years past this would have been addressed by a coalition between the Blancos (PN) and Colorados, the possibilities are such that a merger of this sort would still be insufficient to claim a majority, given the continuing trend of Colorado Party atomization.

Uncertainty characterizes the economic picture as well. Economic deceleration is not a question but a clear fact. What is less clear is whether this soft deceleration will continue or even reverse slightly. The aforementioned free trade agreement with Chile, the construction of the new pulp mill, and other new investments can go a long way in helping the economy to maintain course. But there is a broader environment of unpredictability and contraction at the regional and global levels. This state of affairs, in tandem with a large government workforce and the incertitude of which party or parties will rule, and in what configuration, for the next election cycle are only some of the major questions that will determine the country's economic trajectory.

2019 will, in many ways, be a decisive year for Uruguay. It will also be a decisive year for the region, as the last of the major "Pink Tide" parties tries to maintain its hold on power.

\section{REFERENCES}

Alemán, Eduardo and George Tsebelis. 2011. “Political Parties and Government Coalitions in the Americas." Journal of Politics in Latin America 3 (1): 3-28.

Boglaiccini, Juan A. and Rosario Queirolo. 2017. "Uruguay 2016: Mayorías parlamentarias en jaque y desafíos de revisión para sostener el modelo." Revista de Ciencia Política 37 (2): 589-611.

Bottinelli, Eduardo. 2018, 10 September. “Los movimientos políticos que impactan en la intención de voto. Encuesta Nacional Factum del tercer trimestre de 2018." Factum. Retrieved on 25 March 2019 from https:/ / portal.factum.uy/analisis/2018/ana180910.php

Bottinelli, Eduardo. 2019, 8 March. "Solo el 2\% de los uruguayos sabe que las elecciones internas son el 30 de junio." Factum. Retrieved on 21 March 2019 from https://portal. factum.uy/analisis/2019/ana190308.php

Buquet, Daniel, and Piñeiro, Rafael. 2014. "La consolidación de un nuevo sistema de partidos en Uruguay." Revista Debates 8 (1): 127-148.

12 General Guido Manini Ríos, former Army Commander, was removed from his post on 12 March 2019, by President Tabaré Vázquez, for censuring judicial power (Martínez 2019). He declared his presidential candidacy on 3 April 2019 (La Diaria 2019, 3 April). 
Buquet, Daniel, and Lucía Selios. 2014. "Political Congruence in Uruguay, 2014." In Malaise in Representation in Latin American Countries: Chile, Argentina, and Uruguay, edited by Alfredo Joignat, Mauricio Morales, and Claudio Fuentes. New York: Palgrave McMillan, 187-210.

Caetano, Gerardo. 2017. “ ¿Milagro en Uruguay? Apuntes sobre los gobiernos del Frente Amplio." Nueva Sociedad 272 (noviembre-diciembre): 13-28.

Canzini, Agustín. 2018. "Problemas para el Frente Amplio en Uruguay." Open Democracy. Retrieved on 19 March 2019 from https://www.opendemocracy.net/es/uruguay-el-frente-amplio-en-la-encrucijada /

Carneiro, Fabricio, and Federico Traversa. 2018. “Uruguay 2017: reactivación económica y nuevos conflictos políticos." Revista de Ciencia Política 38 (2): 379-407.

Chasquetti, Daniel. 2007. “Uruguay 2006: éxitos y dilemas del gobierno de izquierda." Revista de Ciencia Política 27 (1): 249-263.

Cifra. 2018, 27 March. "La actitud de los uruguayos hacia los inmigrantes." Retrieved on 26 April 2019 from https://www.cifra.com.uy/index.php/2018/03/27/la-actitud-de-los-uruguayos-hacia-los-inmigrantes /

Cifra. 2019, 6 March. "Intención de voto 'si las elecciones fueran hoy."' Retrieved on 26 April 2019 from https://www.cifra.com.uy/index.php/2019/03/06/intencion-de-voto-silas-elecciones-fueran-hoy-7/

Cifra. 2019, 13 March. "El Presidente Vázquez al comienzo de su último año de gestión." Retrieved on 25 March 2019 from http:/ / www.cifra.com.uy/index.php/2019/03/13/ el-presidente-vazquez-al-comienzo-de-su-ultimo-ano-de-gestion/

Cifra. 2019, 18 March. "El plebiscito sobre seguridad." Retrieved on 25 March 2019 from https:/ / www.cifra.com.uy/index.php/2019/03/18/el-plebiscito-sobre-seguridad/

Corte Electoral República Oriental de Uruguay. n.d.. "Partidos políticos vigentes." Retrieved on 25 April 2019 from https://www.corteelectoral.gub.uy/estadisticas/elecciones_ internas/internas_2019/elecciones_internas_2019

Correa, Juan Pablo. 2018, 18 September. "Ahora sí hay un partido que se define como de 'centroderecha.'” El País. Retrieved on 24 April 2019 from https://www.elpais.com.uy/ informacion/politica/hay-partido-define-centroderecha.html

Departamento de Pscicología Social y Trabajo. N.d. "Las Relaciones Laborales en 2018 y Perspectivas para 2019." Retrieved on 5 April 2019 from https://ucu.edu.uy/sites/default/files/facultad/fce/i_rrll/2018/conflictividad-laboral-informe-anual-2018.pdf

El Observador. 2018, 18 October. "Se aprobó la reforma de la caja militar luego de un año y medio de discusión." Retrieved on 30 April 2019 from https://www.elobservador. com.uy/nota/se-aprobo-la-reforma-de-la-caja-militar-luego-de-un-ano-y-medio-dediscusion-2018101891927

El Observador. 2018, 15 December. “Habrá plebiscito sobre seguridad: Larrañaga anunció que tiene más de 300 mil firmas." Retrieved on 25 March 2019 from https:/ /www.elobservador.com.uy/nota/habra-plebiscito-sobre-seguridad-larranaga-anuncio-que-tiene-mas-de-300-mil-firmas-2018121515167.

El Observador. 2018, 18 December. “Uruguay otorgó más de 50 mil residencias a extranjeros en los últimos cuatro años." Retrieved on 2 May 2019 from https:/ /www.elobservador.com.uy/nota/uruguay-otorgo-mas-de-50-mil-residencias-a-extranjeros-en-losultimos-cuatro-anos-2018121813813

El Observador. 2018, 20 December. "Otra vez Darío Pérez cejó al FA sin el voto 50 y no habrá Ley de Financiamiento de Partidos." Retrieved on 30 April 2019 from https:// www.elobservador.com.uy/nota / diputado-rebelde-del-fa-amenaza-con-no-votar-ley-de-partidos-y-negocian-cambios--20181220133039

EMIA. 2018, 25 June. "Uruguay's FA Agrees to Support Chile FTA." Retrieved on 24 April 2019 from http:/ / www.emia.org/news/story/6066

El País. 2019, 16 April. "Para el diputado Darío Pérez falta comunicación con el gobierno." Retrieved on 30 April 2019 from https://www.elpais.com.uy/informacion/politica/ diputado-dario-perez-falta-comunicacion-gobierno.html\# 
Fitch Ratings. n.d. "Fitch Affirms Uruguay at 'BBB-'; Revises Outlook to Negative." Retrieved on 25 March 2019 from http://deuda.mef.gub.uy/innovaportal/file/25477/1/ fitch-uruguay-rac_05oct2018.pdf

Freire, Germán, Carolina Díaz-Bonilla, Steven Schwartz Orellana, Jorge Soler López, and Flavia Carbonari. 2018. Afrodescendientes en Latinoamérica: hacia un marco de inclusión. Washington: Banco Mundial.

Gil, Valeria. 2018, 2 August. "Mujica se prepara para dejar su cargo de Senador." El País. Retrieved on 5 April 2019 from https://www.elpais.com.uy/informacion/politica/ mujica-prepara-dejar-cargo-senador.html

IMF. 2019. "IMF Country Report 19/64." Washington: International Monetary Fund. Retrieved on 4 April 2019 from https://www.imf.org/ /media/Files/Publications/ CR/2019/1URYEA2019001.ashx

Instituto Nacional de Estadística. 2009. "Estimaciones de pobreza por el método del ingreso 2008." Retrieved on 5 April 2019 from http://www.ine.gub.uy/documents / 10181/35933/Publicacion+Estimaciones+de+Pobreza+por+el+Metodo+del+Ingreso+2008.pdf/ fe7cfcf2-4be4-4329-9fd8-61bed52abf0b

Instituto Nacional de Estadística. 2019. "Estimación de la pobreza por el método del Ingreso 2018." Retrieved on 5 April 2019 from http:/ /www.ine.gub.uy/web/guest/inicio/-/ asset_publisher/qCQOi0UnXKap/content/estimacion-de-la-pobreza-por-el-metodo-de-ingreso-2018/maximized?_101_INSTANCE_qCQOi0UnXKap_redirect=\%2F

La Diaria. 2019, 3 April. "Manini Ríos Presenta Hoy su Candidatura a la Presidencia." Retrieved 30 August 2019 from https:/ /ladiaria.com.uy/articulo/2019/4/manini-rios-presenta-hoy-su-candidatura-a-la-presidencia/

Lánzaro, Jorge. 2011. "Uruguay: A Social Democratic Government in Latin America." In The Resurgence of the Latin American Left, edited by Stephen Levitsky and Kenneth M. Roberts. Baltimore: Johns Hopkins Press, 348-374.

Luna, Juan Pablo. 2007. "Frente Amplio and the Crafting of a Social Democratic Alternative in Uruguay." Latin American Politics and Society 49 (4): 1-30.

Martínez, Magdalena. 2019, 12 March. “El Presidente de Uruguay Destituye al Jefe del Ejército por sus Críticas a los Juicios contra Represores." El País. Retrieved 30 August 2019 from https://elpais.com/internacional/2019/03/12/america/1552413001_068945. html

Ministerio de Economía y Finanzas. n.d. "Fitch Affirms Uruguay at 'BBB-'; Revises Outlook to Negative." Retrieved on 4 April 2019 from http://deuda.mef.gub.uy/innovaportal/ file/25471/1/fitch-uruguay-rac_05oct2018.pdf

Moisá Elicabide, Laura Carla, Jana K. Silverman and María Piñón Pereira Dias. 2018. "Labor and Development in Twenty-First-Century Latin America: Two Political Options." Latin American Perspectives. Advance Online Publication. doi:10.1177/0094582X18806592

Moraes, Juan Andrés, Alejandro Guedes, and Diego Lujan. 2012. “Uruguay: ¿Dónde está el piloto? A dos años de gobierno del presidente Mujica (2010-2011)." Revista de Ciencia Política 32 (1): 269-291.

Moraes, Juan Andrés. 2015. “The Electoral Basis of Ideological Polorization in Latin America." Kellogg Institute for International Studies, Working Paper 403.

Parlamento del Uruguay. n.d.-a. "Integración." Retrieved on 28 June 2019 from https: / parlamento.gub.uy/camarasycomisiones/representantes/plenario/integracion/actuantes

Parlamento del Uruguay. n.d.-b. "Integración." Retrieved on 28 June 2019 from https:// parlamento.gub.uy/camarasycomisiones/senadores/plenario/integracion/actuantes?Lm_Nombre=8

Peralta, José. 2018, 4-10 January. "Cantidad de inmigrantes que solicitan vivir en Uruguay alcanzó un récord histórico y la tendencia es que 'siga aumentando.'" Búsqueda. Retrieved on 26 April 2019 from https:/ / www.busqueda.com.uy/nota/cantidad-de-inmigrantes-que-solicitan-vivir-en-uruguay-alcanzo-un-record-historico-y-la 
Pérez Bentancur, Verónica, Rafael Piñeiro Rodríguez and Fernando Rosenblatt. 2019. “Efficacy and the Reproduction of Political Activism: Evidence from the Broad Front in Uruguay." Comparative Political Studies 52 (6): 838-67.

Pérez, Verónica, and Rafael Piñeiro. 2016. “Uruguay 2015: Los desafíos de gobernar por izquierda cuando la economía se contrae." Revista de Ciencia Política 36 (1): 339-363.

Piñeiro, Diego E., and Joaquín Cardeillac. 2017. "The Frente Amplio and Agrarian Policy in Uruguay." Journal of Agrarian Change." 17 (2): 365-380.

Presidencia. 2019, 16 March. "Murro destacó que 94\% de grupos cerrados de actual ronda de Consejos de Salarios lo hicieron con consenso." Retrieved on 19 March 2019 from https://www.presidencia.gub.uy/comunicacion/comunicacionnoticias/murro-consensos-consejos-salarios-acuerdos-fmi

Programa de Estudios Parlamentarios. n.d-a. "Datos sobre la productividad legislativa en Uruguay / Legislative Productivity of the Uruguayan Congress." Retrieved on 5 April 2019 from http://cienciassociales.edu.uy/bancosdedatos/produccion-parlamentaria-legislacion/

Programa de Estudios Parlamentarios. n.d.-b. Retrieved on 21 March 2019 from https:/ /parlamentosite.wordpress.com/2018/02/17/tasa-de-eficacia-del-pe/

$\mathrm{Su}$, Yen-Pin. 2014. "Explaining Electoral Volatility in Latin America: Evidence at the Party Level." Latin American Politics and Society 56 (2): 49-69.

UNDP. 2018. "Human Development Indices and Indicators: 2018 Statistical Update." Retrieved on 2 May 2019 from https://www.undp.org/content/dam/uruguay/docs/ IDH/undp-uy-nota-informativa-uruguay-2018.pdf

Uruguay XXI. 2018. “Foreign Trade Report." Retrieved on 21 March 2019 from https:/ /www. uruguayxxi.gub.uy/uploads/informacion/10d8897d42fce07bed052e44855edacd37faeeb8.pdf

World Bank. 2019. "Informal Employment (\% of Total Non-Agricultural Employment)." Retrieved on 28 June 2019 from https:/ / data.worldbank.org/indicator/SL.ISV.IFRM.ZS

Yaffé, Jaime. 2013. “Consolidación y transformación partidaria. Institucionalización, liderazgo y capacidad de adaptación en el Frente Amplio de Uruguay." Iberoamericana 13 (50): 7-26.

Received: May 3, 2019

Accepted: July 1, 2019

Erica Townsend-Bell is Associate Professor of Political Science at Oklahoma State University. She obtained her doctorate from the Department of Political Science at Washington University in St. Louis (USA). Her work is published in Political Research Quarterly, Signs, The Oxford Handbook of Gender and Politics, and The Palgrave Handbook of Intersectionality in Public Policy, among other outlets. Email: etowns@okstate.edu 